\title{
THE ATTITUDE OF THE MANAGERS OF THE ENTERPRISES IN THE JIU VALLEY REGARDING THE CURRENT CHANGES IN THE BUSINESS ENVIRONMENT
}

\author{
Mihaela GHICAJANU ${ }^{a^{*}}$ \\ ${ }^{a}$ University of Petrosani, Romania
}

\begin{abstract}
Changes in the current and future business environments are pushing business managers to always be on the alert, looking for viable solutions to constantly adapt, to be able to face reality. The responsibilities of managers are overwhelming and stressful in these conditions, and constantly increasing in the current conditions of permanently changing restrictions generated by the Covid19 pandemic. There are businesses that thrive even in extreme operating conditions and others that go bankrupt. And there are always other new types of business can appear. The question is: "Why do some managers manage to keep the business profitable or even develop it further, and others are unable to do it?" (Collins, 2010). The answer is complex, and this complexity is related to the overall change of the business environment, including the attitude of managers to change, their vision and strategy, the confrontation with reality, etc. In this paper, I will analyse the attitude of business managers in the Jiu Valley and how they act on current challenges / changes. This research is conducted in order to study the response of managers to change, the way they approach these changes and how they come up and look for viable business strategies.
\end{abstract}

KEYWORDS: business, change, leadership, management, strategy, vision.

\section{INTRODUCTION}

In order to see if the answer to the question formulated in the abstract is indeed complex, I conducted pilot research on numerous enterprises in the Jiu Valley, which involves the analysis of several internal and external factors of the business environment.

The question is: "Why do some managers manage to keep the business profitable or even develop it further (even in critical and restrictive situations such as those imposed by the Covid-19 Pandemic), and others are unable to do it?"

The main purpose of the analysis is to identify the attitude and perception of the managers towards change and their reaction when facing situations of risk and uncertainty.

This being a preliminary analysis, the research needs to be extended both in terms of the number of companies included in the investigation, and especially regarding the conceptual point of view of the hypotheses. In order to be useful, this research must be supplemented with additional information and analysis. Further research can also be done by other specialists, institutions, or regional agencies, precisely to support the business environment in the Jiu Valley and to identify viable and realistic solutions for the economic and social recovery of the area.

In the last year, multiple studies have been conducted by different publications, research companies and the National Institute of Statistics, on the subject of the impact of Covid-19 on the business environment and the consequences felt in certain sectors of activity. Most of them were made at a national level, on a large number of companies, analyzing in particular the economic situation and

\footnotetext{
*Corresponding author. E-mail address: ghicajanumihaela@yahoo.com
} 
the economic impact generated by the restrictions imposed by Covid-19. Studies are yet to be conducted on the economic situation of enterprises in the Jiu Valley using the hypotheses presented in this paper. Thus, I consider it necessary to carry out this work, presenting the attitude and thought process of managers from the Jiu Valley in the current crisis situation.

\section{RESEARCH CONTEXT}

\subsection{Research methodology and conditions}

The research methodology is represented by a two-part questionnaire. The questionnaire is designed based on previous personal experiences and analysis (Ghicajanu, 2018), (National Study of Business Process Redesign, 2010), (Verboncu, 2006). The first part of the questionnaire contains 6 questions to identify the data of the respondents, and the second part contains 14 questions. The survey was conducted in March-April 2021, on 34 enterprises in the Jiu Valley, out of a representative number of 64, and the response rate was approximately 53.12 percent of the total.

The companies targeted in the research were mainly in the field of food production and consumer goods, but also in the field of services and construction. Few responses also came from businesses in the field of tourism- hotels, guesthouses and restaurants because it is already known that this segment of activity was very affected by the pandemic. The research focused on analysing the situation of different areas of activity, other than the ones most severely affected by the pandemic. The questionnaires were distributed online on the Google Forms platform.

\subsection{Research hypotheses}

The research hypotheses pursued in the analysis are:

- The attitude and strategic thinking of managers in this crisis situation generated by the pandemic.

- The current economic and financial situation compared to the one in 2020 and 2019.

- The extent and type of changes which took place within companies.

- Managers' perception of the economic situation in the Jiu Valley.

- The main support measures provided by the state or local public administration to small and medium enterprises during this period (if they have received support from the state budget).

- The degree of accessibility to these measures and what are the major problems they faced.

- The degree of accessibility to information and consultancy, necessary for the activities carried out, offered by the authorities in the field or from the state.

- Highlighting the main problems companies faced in the last year, especially from a financial, technical, human and digital point of view.

- Possibility to carry out the activity in the online environment or in the hybrid system.

- The vision of the managers regarding the solutions for continuing the activity and improving the current situation.

\section{RESEARCH RESULTS}

\subsection{Some data about the profiles of the respondents}

The main characteristics of the respondents are:

- The major share is represented by the top managers: manager-boss, general manager (over $80 \%$ ), followed by middle manager (production / quality / economic / commercial) or head of department with $20 \%$ (figure 1). 


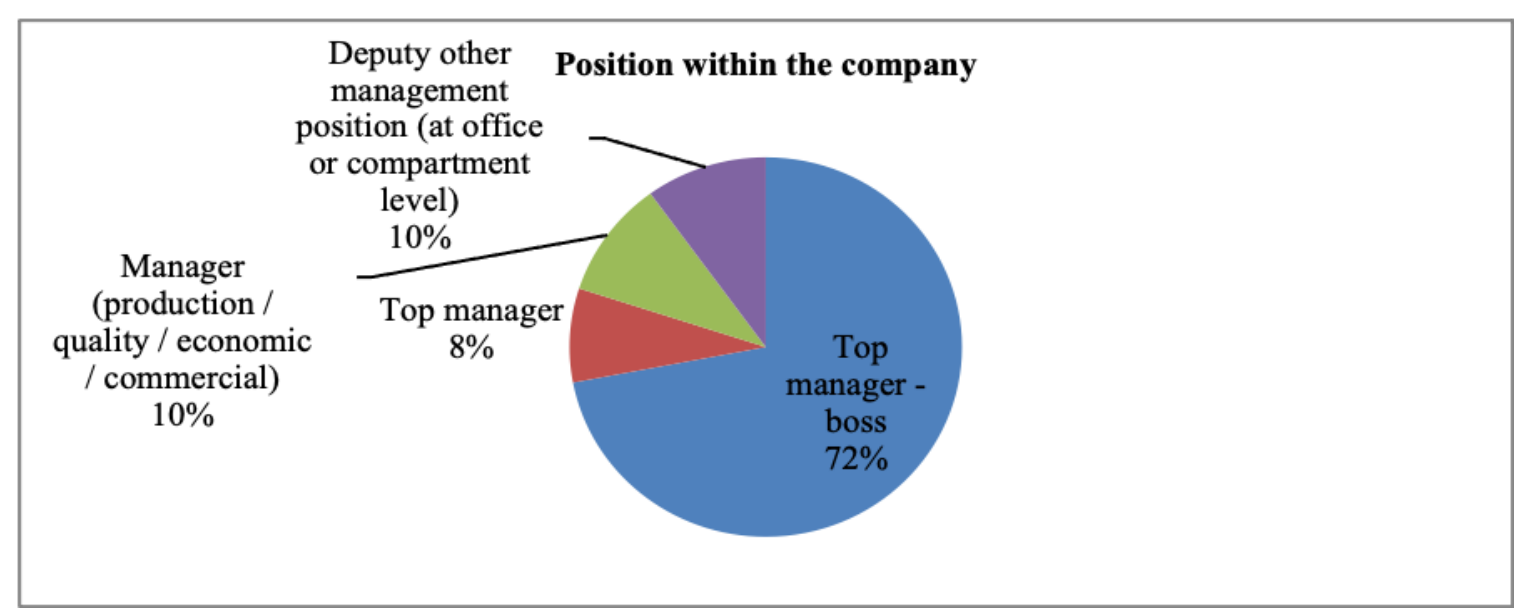

Figure 1. Managerial level

Source: Excel program data processing

- The classification by categories of enterprises, the majority share being represented by small and medium enterprises, which together accumulate $73 \%$ of the total, followed by microenterprises - 18\% and 9\% large enterprises (figure 2).

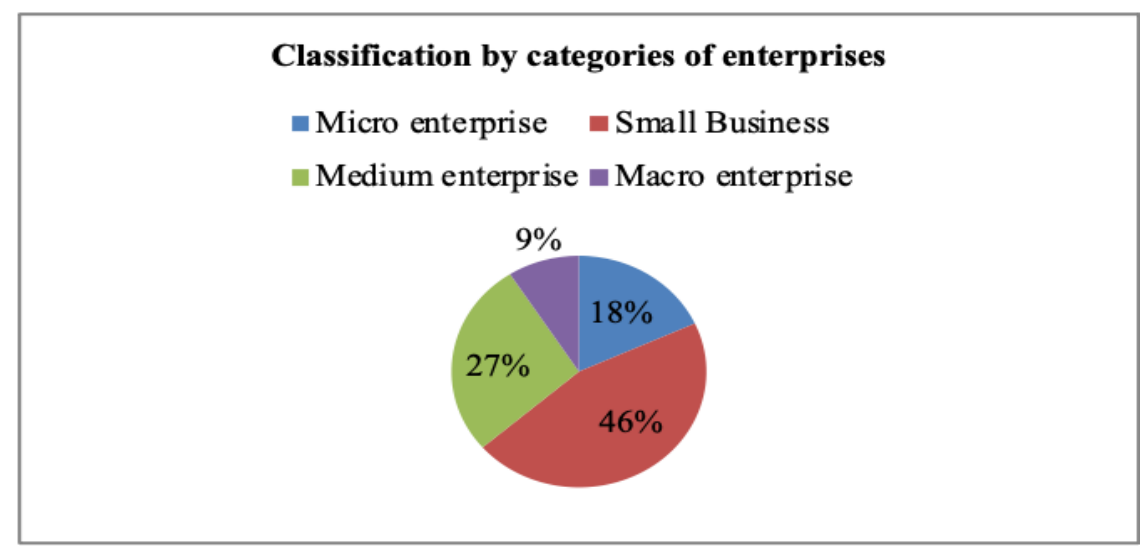

Figure 2. Characteristics of enterprises

Source: Excel program data processing

- The investigated fields are in proportion of $46 \%$ in the domain of food production and consumer goods, constructions with $18 \%$, followed by tourism, insurance, consultancy, other services (each with 9\%), (figure 3). 


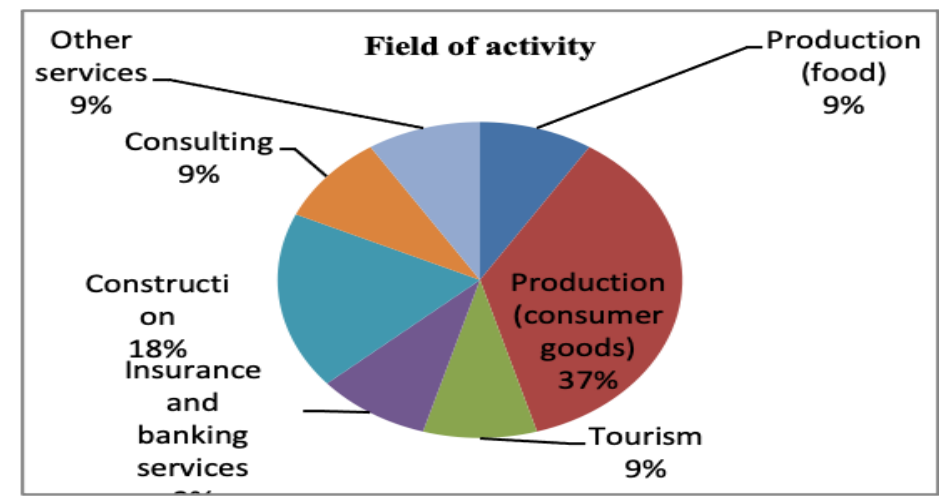

Figure 3. Field of activity

Source: Excel program data processing

- The majority of managers are aged between 31-40 years (27.3\%), between $41-50$ years (27.3\%), between 51-55 years (27.3\%) and only $18.2 \%$ are between $20-25$ years old. (figure 4), and in terms of studies, most have a bachelor's degree $54.4 \%$ and a master's degree $45.5 \%$.

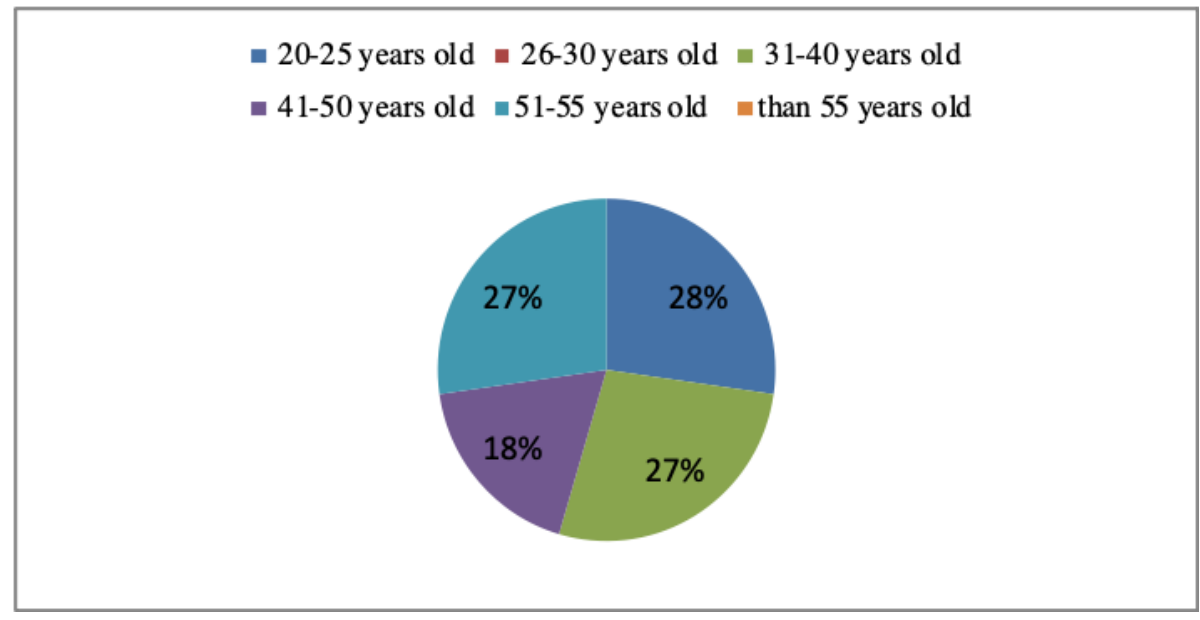

Figure 4. Age of respondents

Source: Excel program data processing

\subsection{The economic-financial situation and the attitude of the managers (figure 5)}

The managers' assessments regarding the state of activity of the enterprises they run, at the level of 2020, compared to 2019, based on the data on turnover and net result for the year, is as follows:

- The majority share belongs to the same situation as in 2019 , for $36.4 \%$ of the respondents.

- For $18.2 \%$ the state of the activity in their companies is satisfactory and also with $18.2 \%$ for other respondents the economic-financial situation in their company is disastrous.

- Surprisingly, there are also better and much better situations than in 2019 , for a total of $27.3 \%$ of companies (respectively a better situation for $18.2 \%$ and much better for $9.1 \%$ of the companies participating in investigation). 


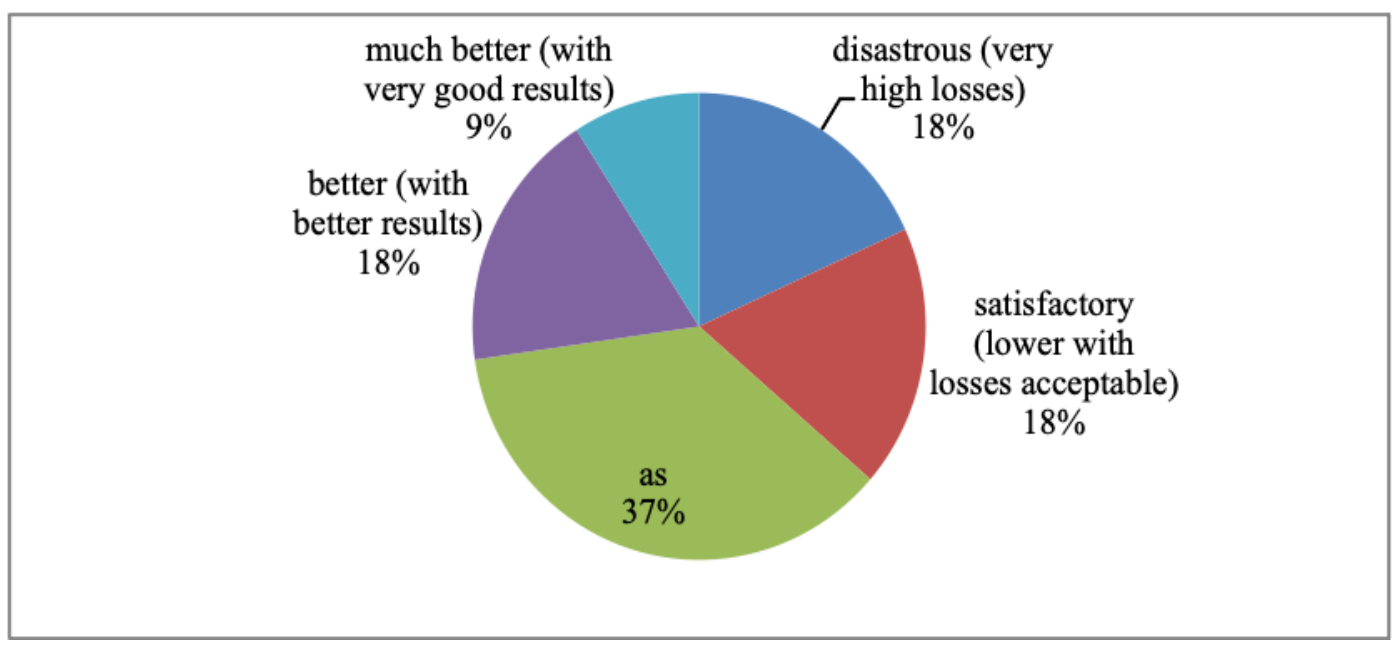

Figure 5. The economic situation in 2020, compared to 2019

Source: Excel program data processing

This situation, which is better and much better in 2020, compared to 2019, for almost a third of enterprises, is explained by the fact that they are mainly part of the food production sector, consumer goods and construction (in total over $65 \%$ of respondents). These companies were hit by the pandemic, but not very severely, and were able to adapt their activity more easily to the newly imposed conditions.

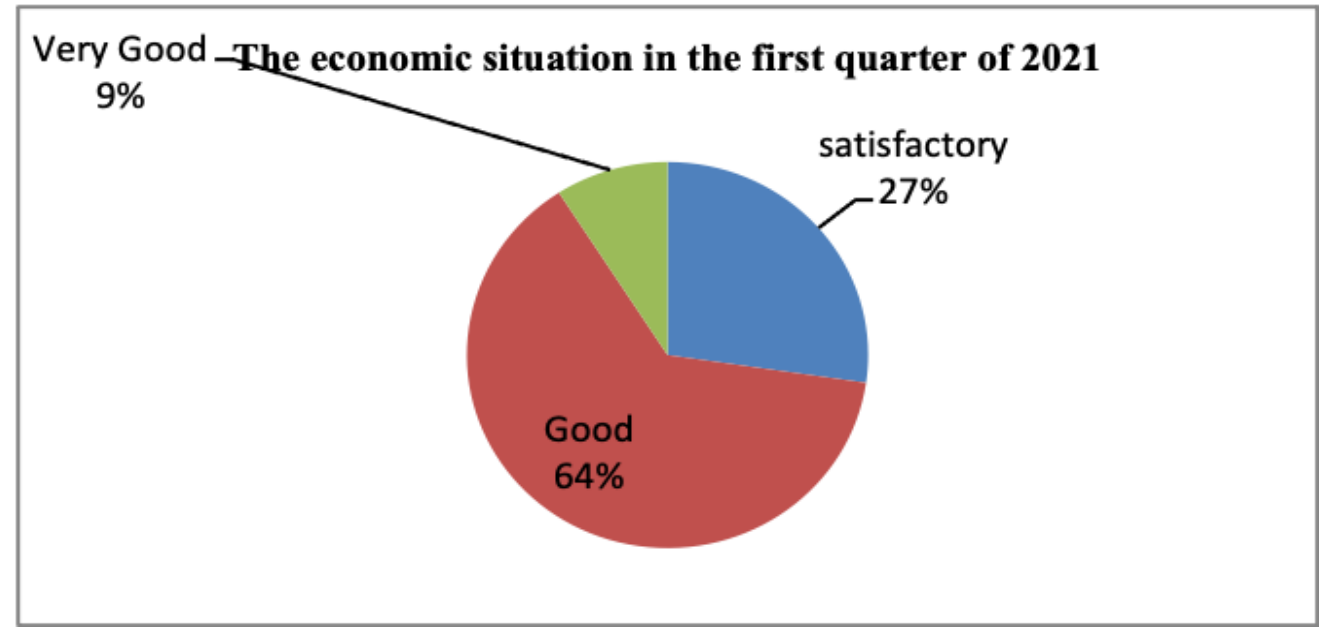

Figure 6. The economic situation in the first quarter of 2021

Source: Excel program data processing

Regarding the current economic and financial situation, respectively at the level of the first quarter of 2021, the situation is maintained at the level of basic survival for $27 \%$ of enterprises, $64 \%$ of enterprises have a good situation and surprisingly, the percentage remains as in 2020, 9.1\% enterprises who are in a better situation (figure 6).

This good and better situation is also related to the fact that managers acted in time and immediately established strategies adapted to the new conditions. This statement results from the answers of the managers, who over 64\% stated that: "when the state of the pandemic was declared at the beginning of 2020 and restrictive measures were imposed, they have already thought of a strategy and they put it into practice", while the rest did nothing, respectively $36 \%$ of the managers, in the sense that "they were worried, but they waited to see how the situation evolves". The attitude of the managers who applied a strategy to the changes caused by the pandemic (64\% of them), coincides exactly 
with the $64 \%$ of companies that said they have a good and better situation in 2021 (at the time of the analysis, March-April).

\subsection{Support for SMEs from the state, local public administration, U.E., business partners}

Regarding the support for SMEs from the local government or public administration, primarily financial support, deferral of taxes or tax exemptions, the situation is as follows (figure 7).

Most of the companies participating in the investigation did not receive any support from the government (around 63\%) and no support from local authorities (82\%). They say they "managed to function" during this period as usual. This term "that they have managed" refers to the fact that they have thought and acted without expecting support from the authorities or the state, because they state that "they do not have much confidence in the measures taken and offered by the authorities and that they cannot rely on these measures".

Only $9.1 \%$ stated that they received financial support from the state, but with great difficulty.

Regarding financial support from European funds, about $27 \%$ of respondents accessed such funds. A significant share stated that they quite often received support from business partners $45 \%$, or from banks $27 \%$. This support consisted mainly of deferred payments (such as business partners suppliers), financial loans provided by banks or deferred payment of debts.

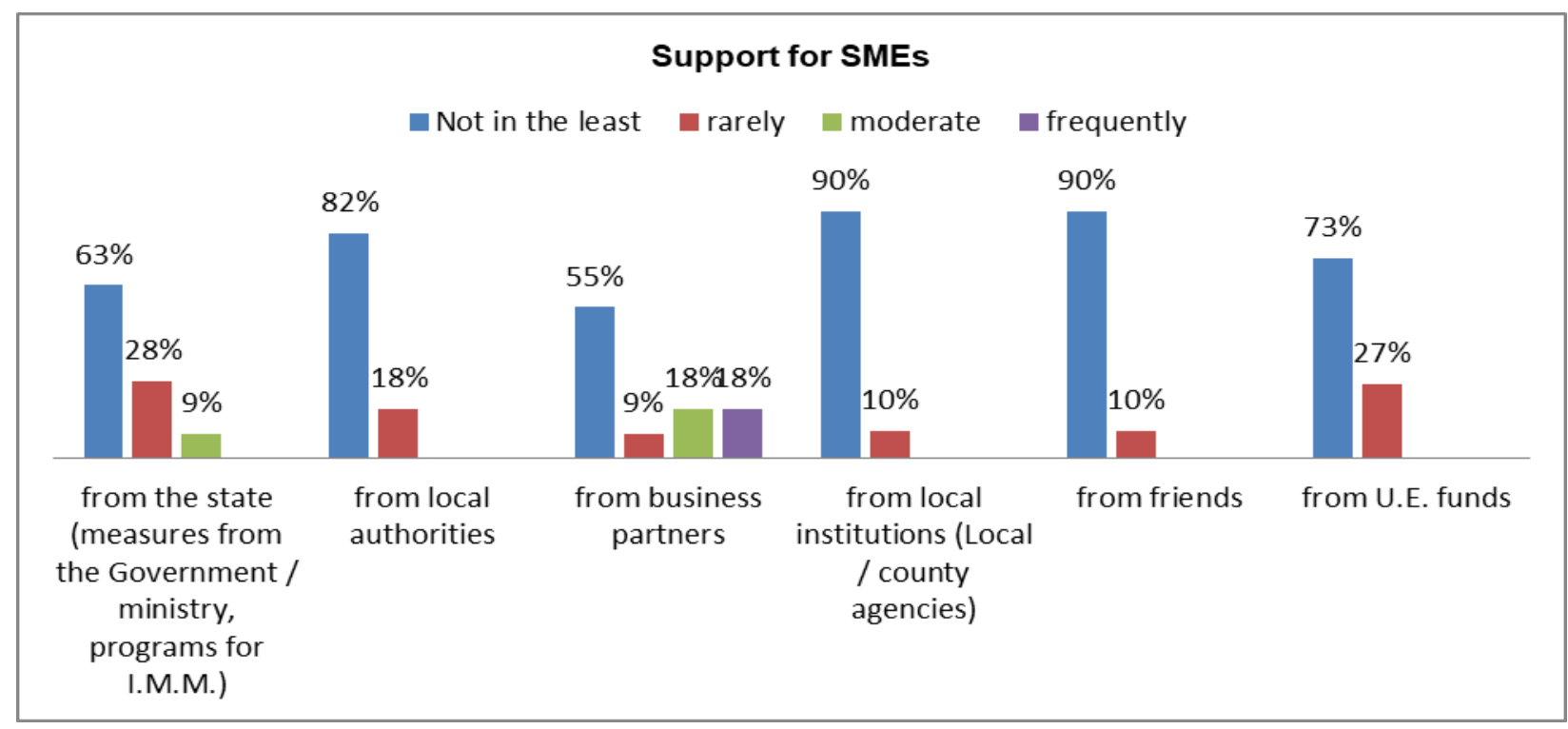

Figure 7. Support for SMEs (especially financial)

Source: Excel program data processing

\subsection{The accessibility degree of financial support from the state or the EU and the major problems they faced.}

Those who received financial support from the state funds (approximately 9.1\%) faced problems such as (figure 9):

- Long and very long delays in the transfer of money (64\%).

- Difficult bureaucracy (64\%).

- Understanding of procedures and methodology for accessing the support (73\%).

The destination of the sums of money received from the state funds was in particular (figure 9):

- Most of the money, up to $50 \%$ of the amount received in $27.7 \%$ of cases, was spent on reorganizing the jobs and workplaces according to safety and health requirements. 
- In the payment of salaries, up to $50 \%$ of the amount received for $18.2 \%$ of cases, and for $9 \%$ of cases, the entire amount of money received as financial support was used to pay employees' salaries.

- For paying of the main suppliers, between $25-50 \%$ of the amount received for $18.2 \%$ of the enterprises.

- In hygiene, cleaning and occupational safety products, between 50-75\% of the amount received for $18.2 \%$ of enterprises.

- Less for the payment of credits or for the payment of utilities, up to $25 \%$ of the amount received for $9 \%$ of cases, both for credits and for the payment of utilities.

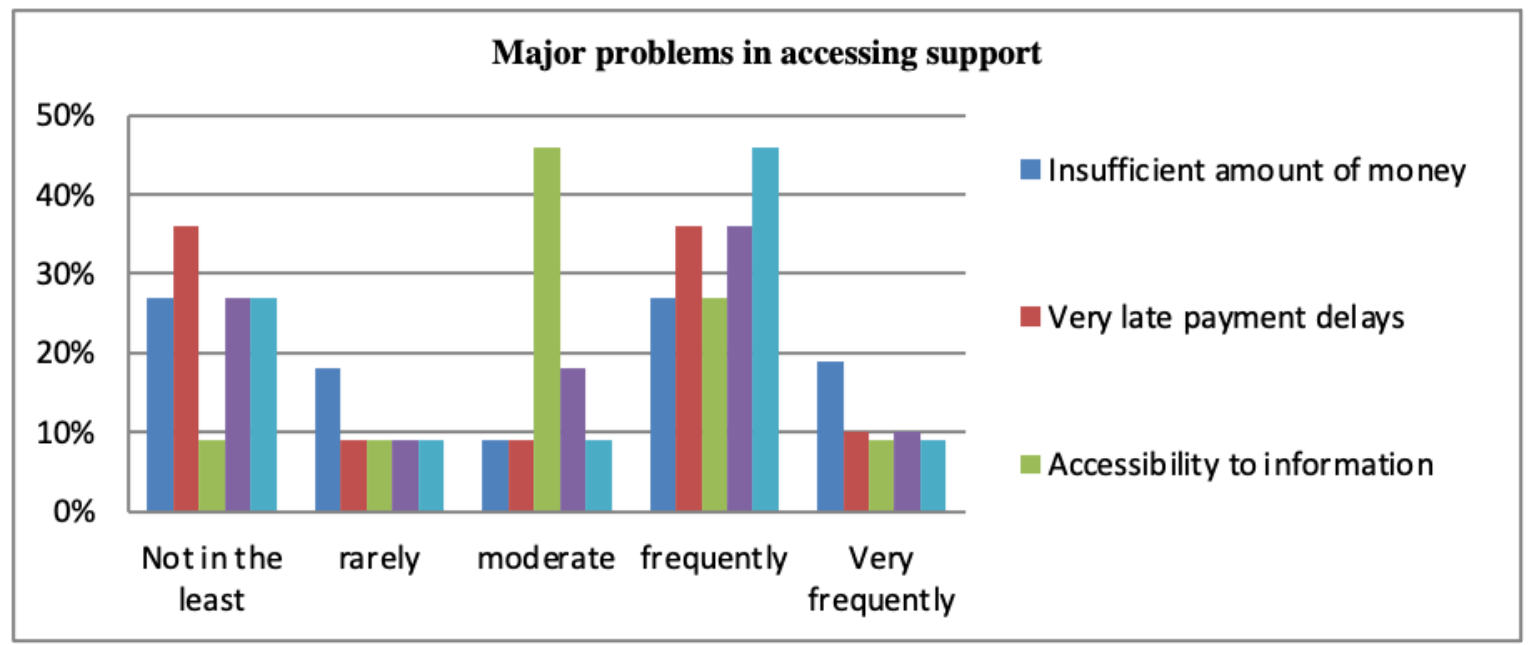

Figure 8. The degree of accessibility of financial support

Source: Excel program data processing

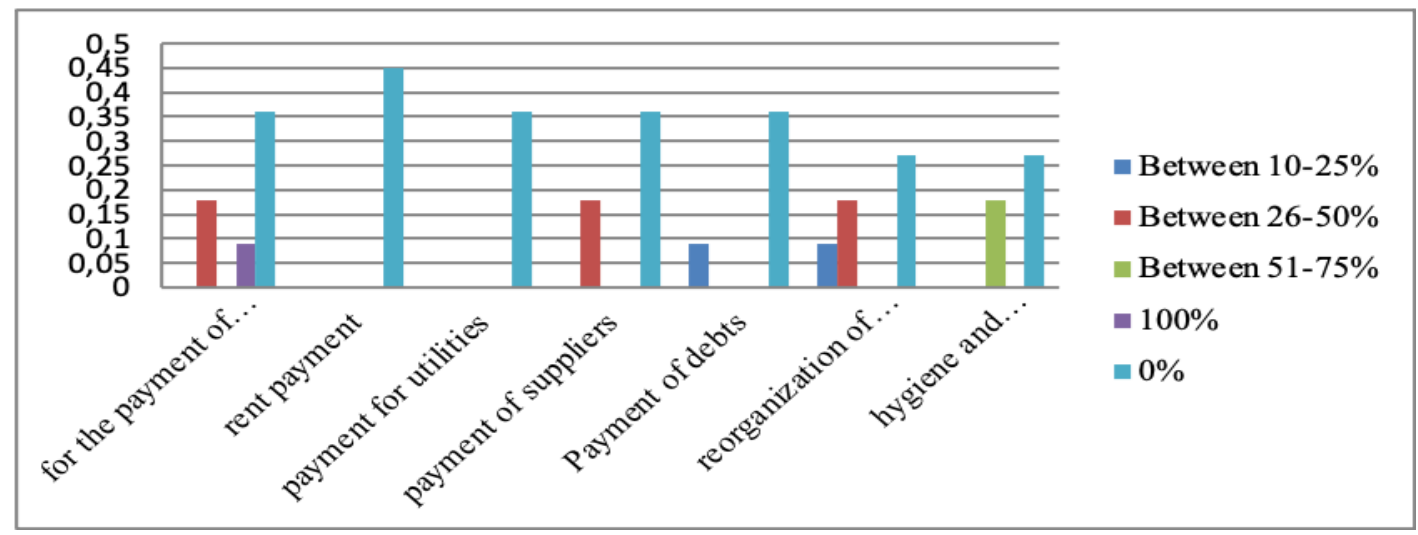

Figure 9. Destination of amounts received as financial support

Source: Excel program data processing

3.5 The degree of accessibility to information and consultancy, necessary for the carried-out activities (figure 10)

The feedback of the respondents regarding the degree of accessibility to the necessary information and how they can access various support measures during the pandemic period, as well as the access to other useful information necessary for carrying out the activities, is as follows: 


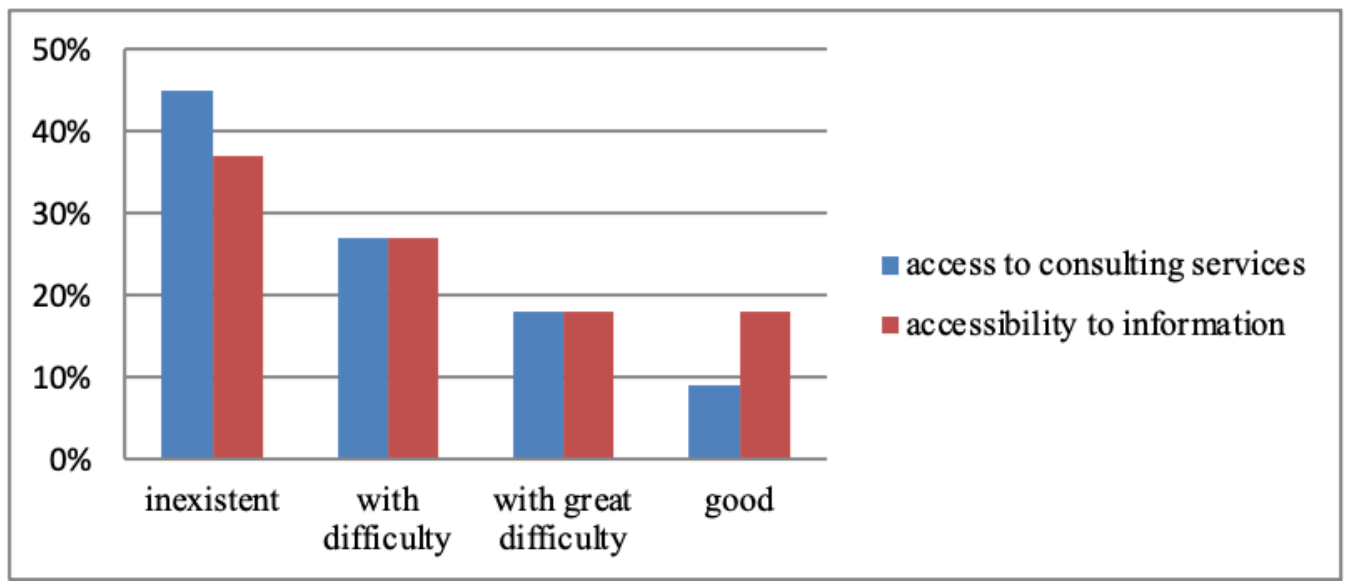

Figure 10. Access to information and consulting services

Source: Excel program data processing

Access to consultancy services provided by the relevant authorities or by the state was non-existent for $45 \%$ of enterprises, with difficulty and great difficulty for another $45 \%$ of enterprises and only $9 \%$ benefited from consultancy services in an accessible way

The situation remains similar to the degree of accessibility to information provided by the authorities, $45 \%$ of companies had difficulty and great difficulty in accessing such information and only $18.2 \%$ said that the necessary information was accessible.

\subsection{Major problems they have faced in the last year}

The main problems faced by companies in 2020 were mainly of financial, technical, digital and human nature. The intensity of these problems was appreciated by most respondents as moderate and very low for (figure.11):

- Human resources problems, in $90 \%$ of cases (enterprises).

- Technical problems, in $74 \%$ of cases.

- Problems of digitization of activities, in $63 \%$ of enterprises.

- On financial issues in $46 \%$ of cases.

The intensity of financial problems was very high for $27 \%$ of enterprises, respectively in insuring capital for: payment of salaries and other expenses and on large issues such as employees for $9 \%$ of cases.

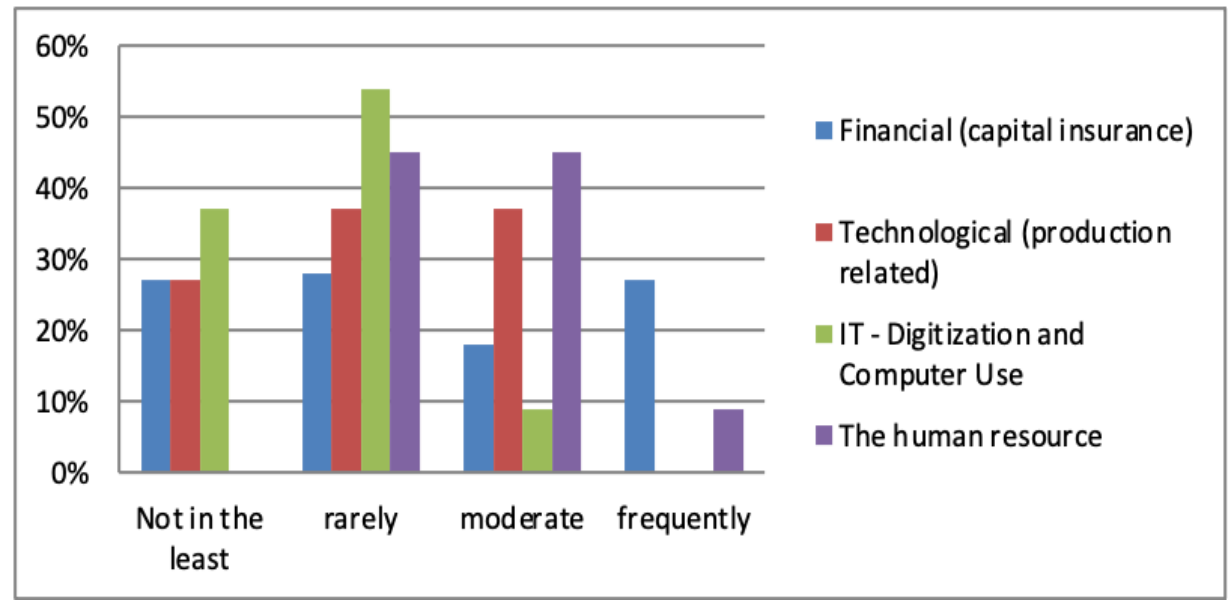

Figure 11. Major problems in the last year

Source: Excel program data processing 


\subsection{The nature of changes in the last year at the level of SMEs}

The biggest changes faced by the investigated enterprises in 2020 and in present times are mainly in the areas of: technical nature, digitization and software programs, reorganizing the activity and, to some extent, human nature and the capability to adapt. The situation is as follows (figure 12):

- Investments in technology are major for $18 \%$ of cases, moderate for $36 \%$, and very little and not at all, with $19 \%$ and $27 \%$ of situations, respectively.

- Investments in digitization and software have been made by $63 \%$ of respondents (of which $45 \%$ have made modest investments of this kind) and $27 \%$ of respondents do not have such investments

- Investments in the reorganization of the activity were applied by all respondents, and the intensity of these changes was high and very high for $18 \%$ of cases, moderate for $63 \%$ of enterprises and slight changes for $18 \%$.

- With regard to staff changes, such as layoffs, most did not use layoffs at $91 \%$ and only $9 \%$ had to let employees go. More so, $54 \%$ from the $91 \%$ who did not have to let employees go, hired staff in the last year of operation to a small and moderate extent.

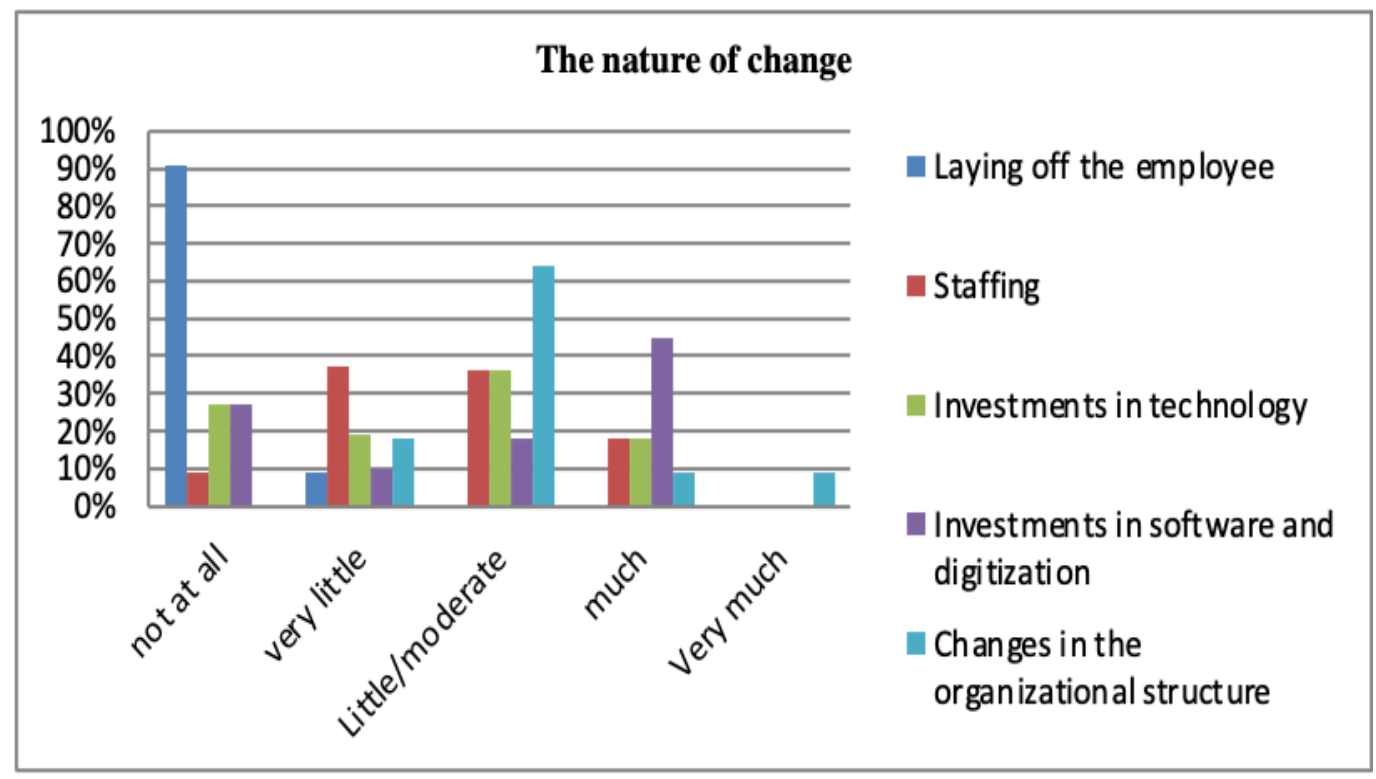

Figure 12. The nature of change in the last year (2020)

Source: Excel program data processing

\subsection{The way of working}

Regarding the working conditions, there were no situations in which the entire activity could take place in the online environment. Most enterprises, due to the nature of the production activities, had to reorganize their jobs taking in consideration the health conditions and thus $64 \%$ continued their work and activity entirely at the company or production departments, and in $36 \%$ of cases it was possible to perform tasks in the hybrid system - at the company and online (figure13). 


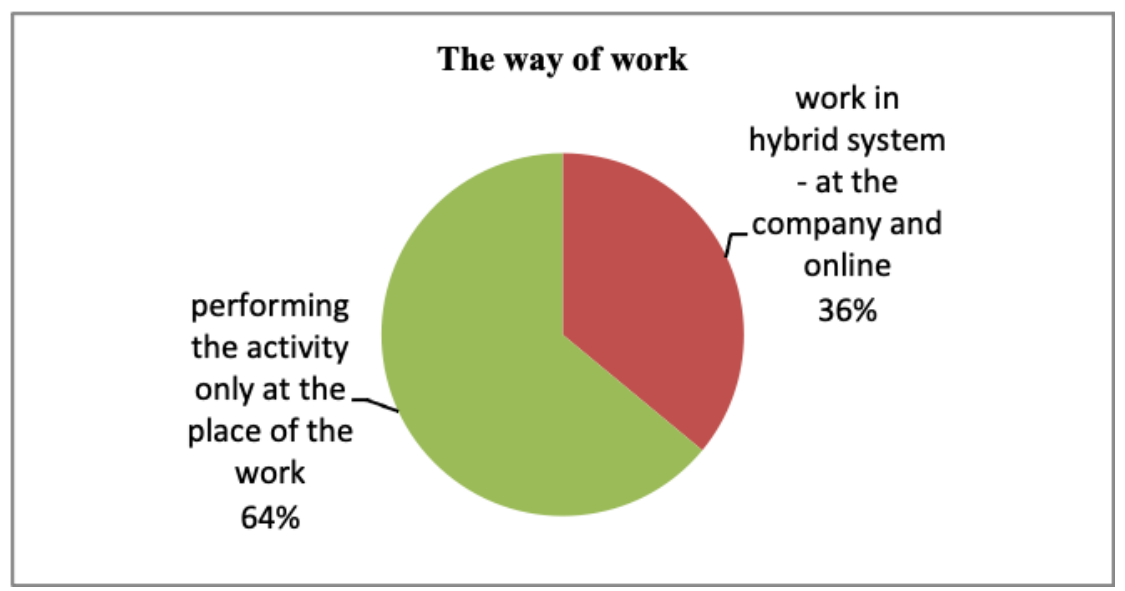

Figure 13. The way of working in the last year, 2020, and now

Source: Excel program data processing

\section{CONCLUSIONS}

The conclusions of this preliminary study, carried out on a limited number of companies in the Jiu Valley, show that most of the problems they faced, in addition to the financial and day-to-day activities under normal conditions before the pandemic, are:

- Those related to the lack of sufficient measures from local and central authorities.

- Poor involvement and very little support from them.

- Bureaucracy and difficult legislation.

- The difficulty of accessing information and consulting services.

The managers also appreciate that the situation of enterprises in the Jiu Valley is very difficult compared to other regions of the country. This difficult situation is determined by several factors, the major ones being:

- The area has been predominantly mono-industrial for many years - the coal mining industry and the industries directly or indirectly related to this activity.

- The emigration of young people to other regions of the country and other European countries.

- Predominantly aged population.

- A big number of socially assisted persons.

- Lack of investment in infrastructure (very little access to money from European funds).

- Lack of interest of local authorities in measures to stimulate investors and to aid the development of the area.

Among the measures suggested by the interviewed managers are:

- The East-West opening of the Jiu Valley by finalizing the roads currently under construction.

- The unitary approach of the tourist field in the Jiu Valley and marketing actions of the area which is much underestimated compared to reality.

- Several activities for young people, setting up nurseries, smart city solutions.

- Major investments in professional reform.

- A refurbishment of mining based on a study done together with professors from the Faculty of Mining at the University of Petroșani together with specialists.

- Granting a higher rate of own contribution than in the Western Region for accessing European funds.

- Directing public investment towards viable and sustainable projects aimed at creating an attractive and business-friendly environment for investors. 
- Administrative-territorial reorganization of the area to allow access to non-reimbursable funds for agricultural policy.

- Encouraging the circular economy.

- Accessible EU funding.

- Lower contribution, for accessing European funds.

- Investments in infrastructure.

- Lack of professional reconversion and development of touristic areas.

The main conclusion, which I can formulate based on this study, is that the managers of enterprises in the Jiu Valley are real fighters. They want the Jiu Valley to prosper, they want young people and young workers to stay in the Valley, they want well prepared and qualified employees and they have viable solutions and ideas. However, most of these solutions must be applied either by local authorities or together through public-private partnerships. It is important to act and not wait on the principle "I am worried, but we'll wait and see what happens".

\section{ACKNOWLEDGMENT}

I would like to give special thanks to Liliana Scarlat, the director of "Mondo Cariere" agency in Petroșani, who helped me with distributing the questionnaires to some of the investigated companies.

\section{REFERENCES}

Ciobanu, I., Ciulu, R. (2005). Strategiile competitive ale firmei, Editura Polirom, Iaşi.

Collins, J. (2010). Excelenţa în afaceri: de ce anumite companii reuşesc saltul de la „,bun” la Excelent”, iar altele nu? " Editura Curtea Veche, Bucureşti.

Diaconu, M. (2011). Inovaţia tehnologică, concept, proces, tipologie, implicaţii în economie, Economie teoretică şi aplicată, Vol. XVIII, 10(563), 107-124.

Edelhauser, E. (2011), Studiu privind I.M.M- urile din Bazinul Văii Jiului. IMM-urile şi Tehnologia Informaţiei, soluţii alternative pentru dezvoltarea Văii Jiului, Petroşani.

Ghicajanu, M. (2018). The Performance Management Process - a Necessity in the Success of a Business Redesign Program, Review of Management and Economic Engineering International Management Conference, Proceedings Paper, 309-314.

Nicolescu, O., Verboncu, I. (2001). Metodologii manageriale, Editura Tribuna Economică, Bucureşti.

Popa, I. (2005). Tipuri de strategii în functiie de dinamica obiectivelor, Tribuna Economică, 16 (48).

Puiu, A 1. (2007). Management. Analize şi studii comparative, Ediţia a-3-a, Editura Independenţa Economică, Piteşti.

Verboncu, I. (2000). Manageri şi management, Editura Economicã, Bucureşti.

Verboncu, I. (2006). Managerial Re-engineering of the Organization, Buletinul Universităţii Petrol - Gaze din Ploieşti, LVIII (2).

National Study of Business Process Redesign, (2010). Insight Management Consulting, Romania. 